\title{
Role of occult blood loss in anaemia after partial gastrectomy
}

I. MCLEAN BAIRD, ${ }^{1}$ D. J. B. ST. JOHN, ${ }^{2}$ AND SHAFIKA S. NASSER ${ }^{3}$

From the West Middlesex Hospital, Isleworth, Middlesex

SUMMARY The present investigation is a study of occult gastrointestinal blood loss in 20 anaemic postgastrectomy patients and 14 control subjects. One patient in the postgastrectomy group was found to be bleeding from undetected haemorrhoids. One patient in each group showed sensitivity to aspirin with greatly increased occult blood loss.

The mean blood loss in 18 postgastrectomy patients with unexplained anaemia was $0.6 \pm$ $0.5 \mathrm{ml} /$ day compared with $0.5 \pm 0.5 \mathrm{ml} /$ day in 13 control subjects. Only two of the 19 anaemic postgastrectomy patients studied lost more than $2 \mathrm{ml}$ blood/day.

Aspirin blood loss in 18 postgastrectomy patients was $2 \cdot 4 \pm 2 \cdot 1 \mathrm{ml} /$ day, compared with $2.6 \pm 2.7 \mathrm{ml} /$ day in 13 controls. The pattern of aspirin blood loss is identical in both groups.

All gastric biopsies obtained from nine patients with Polya gastrectomies showed changes of gastritis; some showed complete gastric atrophy and intestinal metaplasia.

Occult gastrointestinal bleeding is not an important factor in the pathogenesis of anaemia after partial gastrectomy unless there is either stomal ulceration or a lesion completely unrelated to the partial gastrectomy. If occult bleeding is present after partial gastrectomy a careful search for the site of bleeding is indicated.

Excessive intake of aspirin or increased sensitivity to aspirin was not shown to be a significant factor in the pathogenesis of the anaemia in this group of patients. However, because of the inability to augment iron absorption to compensate for blood loss, it would be inadvisable for the patient with a partial gastrectomy to take a high dosage of aspirin for long periods of time, unless aspirin-induced blood loss is measured and shown to be very low. Aspirin administered in low dosage is not contraindicated after partial gastrectomy.

Iron-deficiency anaemia occurs frequently after partial gastrectomy, and malabsorption of dietary iron is one factor in its pathogenesis (Baird and Wilson, 1959; Turnberg, 1966). The exact role of

1Please request reprints from Dr I. McLean Baird.

'Present address: Clinical Research Unit, Alfred Hospital, Melbourne, 3181, Australia

2'In receipt of grants from the North West Metropolitan Regional Hospital Board Research Fund and from the Medical Research Fund of the West Middlesex Hospital blood loss is still undetermined, but there is a steep fall in haemoglobin levels in premenopausal women who have a partial gastrectomy (Baird, Blackburn, and Wilson, 1959). Iron loss due to bleeding is badly tolerated in these patients, and this may be due to inability to make up the iron deficit because the physiological augmentation of iron absorption fails to occur after partial gastrectomy. 
Continual or intermittent occult blood loss from the alimentary tract is another possible explanation of the iron-deficiency anaemia after partial gastrectomy which has received scant attention. Kimber, Patterson, and Weintraub (1967) found gastrointestinal blood loss in six out of eight postgastrectomy patients with irondeficiency anaemia, but Stevens, Pirzio-Biroli, Harkins, Nyhus, and Finch (1959) observed occult alimentary bleeding in only two out of seven anaemic postgastrectomy patients. The present work shows that the basal occult blood loss from the gastrointestinal tract and the occult blood loss after large doses of aspirin is not significantly different from control subjects. This study suggests that when occult bleeding is present in an anaemic postgastrectomy patient, a careful search for a cause unrelated to the gastrectomy is indicated.

\section{Patients Studied}

Twenty patients who presented with irondeficiency anaemia without obvious cause after Polya partial gastrectomy were investigated to determine basal faecal blood loss and faecal blood loss after a large dose of soluble aspirin. The initial low haemoglobin levels were restored to normal with intravenous Imferon or oral iron before the study. All patients had been investigated with barium studies and sigmoidoscopy and no cause for gastrointestinal bleeding had been found. One patient, who initially denied having rectal bleeding, later noticed some rectal blood when performing stool collections (case 12, Table I), and a further sigmoidoscopy revealed small haemorrhoids. Although his results are presented, they have been excluded from the calculation of the results for the group as a whole. All patients were asked about their usual aspirin intake and the intake was classified as shown in Table I. Menstrual periods were occurring in two of the eight female patients with apparently normal menstrual loss and two others were recently menopausal.

Gastrointestinal blood loss was also measured in 14 control subjects. These subjects were fully ambulant hospital inpatients who had no evidence of gastrointestinal haemorrhage and no history of aspirin sensitivity (Table II). One patient had previously had anaemia due to menorrhagia, and had been successfully treated with Imferon infusion before the study. The patients with myocardial infarction were not receiving anticoagulants. radiochromium. Ten $\mathrm{ml}$ of patient's blood was washed with a buffered citrate solution, $p \mathbf{H} 6.9$, and the washed red cells were labelled with $100 \mu \mathrm{c}$ of sodium chromate $\left(\mathrm{Na}_{2}{ }^{51} \mathrm{Cr} \mathrm{O}^{4}\right)$ (Mollison, 1961). Sodium chromate, with a specific activity of 50 to $150 \mathrm{c} / \mathrm{g}$, was obtained from the Radiochemical Centre, Amersham. The labelled red cells were reinjected into the patient after three washings in normal saline. Five $\mathrm{ml}$ of the patient's blood was drawn either 15 minutes later or 24 hours later. Further samples were obtained at intervals of one week for the duration of the investigation. Faecal collections were begun two days after injection of the labelled blood and were continued for three weeks. A scintillation counter with an IDL 1700 scaler and a 2 in. thallium-activated sodium iodide well crystal were used to measure the radioactivity of the samples. The lead castle was modified to hold a $300 \mathrm{ml}$ plastic bottle above the crystal and the homogenized faecal specimens and the blood samples, diluted in each case to $300 \mathrm{ml}$, were counted in these bottles. With this arrangement the count rate for $1.5 \mathrm{ml}$ blood one week after labelling was equal to the background count rate, which was normally $80-120$ counts/100 seconds. The radioactivity of the blood was estimated for each day in the three-week period and the volume of blood in the faeces was calculated by comparing the radioactivity of the faeces with that of the blood, allowance being made for the gastrointestinal transit time. The radiochromium method assures that any radioactivity in the stools is due to patient's red cells, and is an accurate measurement of blood loss (Owen, Bollman, and Grindlay, 1954).

Faecal collections were made for 10 days before aspirin, one week during the administration of aspirin, and for a further four days without aspirin. Blood loss was expressed as mean blood loss per day, for the basal period, and as mean blood loss per day of treatment for the period on aspirin. Aspirin was administered in four doses per day. Eighteen of the postgastrectomy patients and the 14 control patients were started on $3.6 \mathrm{~g}$ of aspirin daily but nine postgastrectomy patients and three control patients could not tolerate this dose, and in these patients the dosage was reduced to $2.4 \mathrm{~g}$ daily.

Gastric biopsies were performed in nine postgastrectomy patients using a modified Wood's gastric biopsy tube (Wood, Doig, Motteram, and Hughes, 1949; Coghill and Williams, 1955). Two biopsies were taken under radiological control in each patient, one from the gastric remnant close to the gastrooesophageal junction and the other further down towards the stoma. 
anaemic postgastrectomy group (Table I), with a mean age of 56 years. The interval between the operation and the present investigation ranged between four and 24 years with a mean of 14 years. The mean haemoglobin level before treatment was $8.1 \mathrm{~g} / 100 \mathrm{ml}$ and stainable iron was absent from the bone marrow in every case. All patients received a full course of iron, either parenterally or orally, before the study. The peripheral blood film and haemoglobin had returned to normal in every instance and the mean haemoglobin after treatment was $13.6 \mathrm{~g} /$ $100 \mathrm{ml}$. One patient was losing $4.3 \mathrm{ml} /$ day of blood due to haemorrhoids (case 12, Table I). There was one patient with aspirin sensitivity in this group, who lost up to $78 \mathrm{ml}$ of blood in one day (Fig. 1). Both these patients were excluded from the calculation of the means of the group. The result of the enquiry into aspirin consumption by the anaemic postgastrectomy patients is shown in Table I. There was no correlation between aspirin intake and severity of anaemia. One patient was consuming between 0.6 and $1.8 \mathrm{~g}$ aspirin daily because of tabetic pains. His mean blood loss on $3.6 \mathrm{~g}$ of aspirin during the study was $1.9 \mathrm{ml} /$ day. This patient wss the only one in the group who was taking regular large doses of aspirin.

There were six males and eight females in the control group and the clinical data are shown in Table II. The mean age of control subjects was 54 years. One patient in the control group showed aspirin sensitivity, losing up to $120 \mathrm{ml}$ of blood in one day, and this patient was also excluded.

\begin{tabular}{|c|c|c|c|c|c|c|c|c|c|}
\hline \multirow[t]{2}{*}{ Case } & \multirow[t]{2}{*}{ Age } & \multirow[t]{2}{*}{ Sex } & \multirow{2}{*}{$\begin{array}{l}\text { Date of } \\
\text { Partial } \\
\text { Gastrectomy }\end{array}$} & \multirow{2}{*}{$\begin{array}{l}\text { Usual } \\
\text { Aspirin } \\
\text { Intake }\end{array}$} & \multicolumn{2}{|c|}{$\begin{array}{l}\text { Haemoglobin } \\
(\mathrm{g} / 100 \mathrm{ml})\end{array}$} & \multirow{2}{*}{$\begin{array}{l}\text { Mean Basal } \\
\text { Blood Loss } \\
\text { (ml/day) }\end{array}$} & \multirow{2}{*}{$\begin{array}{l}\text { Mean Blood } \\
\text { Loss with } \\
\text { Aspirin } \\
\text { (ml/day) }\end{array}$} & \multirow{2}{*}{$\begin{array}{l}\text { Increased Blood } \\
\text { Loss due to } \\
\text { Aspirin } \\
\text { (ml/day) }\end{array}$} \\
\hline & & & & & $\begin{array}{l}\text { Before } \\
\text { Iron }\end{array}$ & $\begin{array}{l}\text { After } \\
\text { Iron }\end{array}$ & & & \\
\hline 1 & 45 & $\mathbf{M}$ & 1949 & 0 & 6.8 & $15 \cdot 7$ & $2 \cdot 4$ & $8 \cdot 7$ & $6 \cdot 3$ \\
\hline 2 & 42 & $\mathbf{M}$ & 1962 & + & $6 \cdot 1$ & $14 \cdot 7$ & 2.6 & $35 \cdot 3$ & $32 \cdot 7$ \\
\hline 3 & 65 & $\mathbf{F}$ & 1943 & $+t$ & 6.6 & $13 \cdot 5$ & 0.5 & 0.9 & 0.4 \\
\hline 4 & 62 & $\mathbf{M}$ & 1952 & 0 & $7 \cdot 8$ & $13 \cdot 3$ & 0.4 & $1 \cdot 3$ & 0.9 \\
\hline 5 & 49 & $\mathbf{M}$ & 1947 & \pm & 8.5 & $14 \cdot 3$ & 0.7 & 3.0 & $2 \cdot 3$ \\
\hline 6 & 48 & $\mathbf{M}$ & 1949 & $\bar{t}+$ & $10 \cdot 4$ & $15 \cdot 3$ & 0.3 & $1 \cdot 3$ & 1.0 \\
\hline 7 & 70 & $\mathbf{M}$ & 1952 & \pm & $9 \cdot 0$ & $12 \cdot 4$ & $1 \cdot 2$ & $4 \cdot 6$ & 3.4 \\
\hline 8 & 52 & $\mathbf{F}$ & 1948 & \pm & $7 \cdot 0$ & $14 \cdot 3$ & 0.4 & $1 \cdot 3$ & 0.9 \\
\hline 9 & 46 & $\mathbf{F}$ & 1963 & $\overrightarrow{0}$ & 9.0 & $13 \cdot 3$ & 0.4 & 0.7 & 0.3 \\
\hline 10 & 61 & $\mathbf{M}$ & 1952 & + & 9.5 & $14 \cdot 2$ & 0.7 & $2 \cdot 1$ & 1.4 \\
\hline 11 & 50 & $\mathbf{M}$ & 1953 & $+t+$ & $4 \cdot 5$ & $14 \cdot 7$ & 0.4 & 1.9 & 1.5 \\
\hline 12 & 66 & $\mathbf{M}$ & 1954 & 0 & $6 \cdot 1$ & $11 \cdot 7$ & $4 \cdot 3$ & $4 \cdot 2$ & 0 \\
\hline 13 & 66 & $\mathbf{M}$ & 1962 & + & 10.5 & $12 \cdot 7$ & 0.4 & $2 \cdot \overline{7}$ & $2 \cdot 3$ \\
\hline 14 & 64 & $\mathbf{M}$ & 1952 & \pm & $10 \cdot 8$ & $13 \cdot 3$ & 0.6 & 6.4 & $5 \cdot 8$ \\
\hline 15 & 37 & $\mathbf{F}$ & 1959 & $\overline{0}$ & 4.5 & $12 \cdot 6$ & 0.4 & 1.6 & $1 \cdot 2$ \\
\hline 16 & 61 & $\mathbf{M}$ & 1948 & 0 & $10 \cdot 2$ & $15 \cdot 3$ & 0.4 & $1 \cdot 3$ & 0.9 \\
\hline 17 & 69 & $\mathbf{F}$ & 1948 & + & $10 \cdot 2$ & $14 \cdot 2$ & 0.4 & 1.0 & 0.6 \\
\hline 18 & 46 & $\mathbf{F}$ & 1961 & + & 6.5 & $11 \cdot 5$ & 0.7 & $1 \cdot 2$ & 0.5 \\
\hline 19 & 62 & $\mathbf{F}$ & 1952 & 0 & $10 \cdot 2$ & $11 \cdot 7$ & 0.4 & $2 \cdot 4$ & 2.0 \\
\hline 20 & 58 & $\mathbf{F}$ & 1952 & ++ & $7 \cdot \overline{5}$ & $12 \cdot 4$ & 0.2 & 0.9 & 0.7 \\
\hline
\end{tabular}

Table I Blood loss before and after aspirin administration in 20 anaemic postgastrectomy patients

$10 \mathrm{Nil}$

\pm Minimal and infrequent, eg, 4 tablets/year

+ Minimal and occasional, eg, $2-4$ tablets $/ 3$ months

++ Moderate and regular, eg, 4-6 tablets/week

+++ Regular daily, eg, 2-6 tablets/day

\begin{tabular}{|c|c|c|c|c|c|c|c|}
\hline Case & Age & Sex & Diagnosis & $\begin{array}{l}\text { Haemoglobin } \\
(\mathrm{g} / 100 \mathrm{ml})\end{array}$ & $\begin{array}{l}\text { Mean Basal } \\
\text { Blood Loss } \\
\text { (ml/day) }\end{array}$ & $\begin{array}{l}\text { Mean Blood } \\
\text { Loss with } \\
\text { Aspirin } \\
\text { (ml/day) }\end{array}$ & $\begin{array}{l}\text { Increased Blood } \\
\text { Loss due to } \\
\text { Aspirin } \\
\text { (ml/day) }\end{array}$ \\
\hline 1 & 64 & $\mathbf{M}$ & Myocardial infarction and bronchitis & $14 \cdot 2$ & 0.9 & 6.5 & 5.6 \\
\hline 2 & 64 & $\mathbf{M}$ & Chronic bronchitis & 13.8 & 0.5 & $1 \cdot 3$ & 0.8 \\
\hline 3 & 38 & $\mathbf{F}$ & Paroxysmal tachycardia & $12 \cdot 8$ & - & 2.0 & - \\
\hline 4 & 50 & $\mathbf{M}$ & Headache & $12 \cdot 6$ & 1.8 & $9 \cdot 3$ & 7.5 \\
\hline 5 & 43 & $\mathbf{F}$ & Pneumonia & $11 \cdot 4$ & $0 \cdot 3$ & 1.4 & $1 \cdot 1$ \\
\hline 6 & 75 & $\mathbf{F}$ & Myocardial infarction & $12 \cdot 6$ & $0 \cdot 1$ & 0.3 & 0.2 \\
\hline 7 & 47 & $\mathbf{M}$ & Myocardial infarction & $16 \cdot 7$ & 0.1 & 0.8 & 0.7 \\
\hline 8 & 54 & $\mathbf{F}$ & Pleural effusion & $12 \cdot 6$ & 0.4 & $4 \cdot 3$ & 3.9 \\
\hline 9 & 51 & $\mathbf{F}$ & Anaemia & $8 \cdot 2$ & $0 \cdot 2$ & 1.0 & 0.8 \\
\hline 10 & 39 & $\mathbf{F}$ & Hypertension & $14 \cdot 2$ & $0 \cdot 1$ & $1 \cdot 1$ & 1.0 \\
\hline 11 & 48 & $\mathbf{M}$ & Asthmatic bronchitis & 14.5 & 0.2 & $\mathbf{3} \cdot \mathbf{3}$ & $3 \cdot 1$ \\
\hline 12 & 55 & $\mathbf{M}$ & Myocardial infarction & 14.9 & 0.5 & 0.6 & 0.1 \\
\hline 13 & 62 & $\mathbf{F}$ & Angina pectoris & $12 \cdot 6$ & 0.7 & 1.5 & 0.8 \\
\hline 14 & 69 & $\mathbf{F}$ & Hypertension and eczema & $11 \cdot 9$ & 0.7 & $23 \cdot 3$ & $22 \cdot 6$ \\
\hline
\end{tabular}

Table II Blood loss before and after aspirin administration in 14 control patients 
COMPARISONS BETWEEN POSTGASTRECTOMY AND CONTROL GROUPS

Comparisons between the two groups are shown in Table III. No differences in basal bleeding patterns were observed: the mean daily basal blood loss was $0.6 \pm 0.5 \mathrm{ml} /$ day in 18 postgastrectomy patients, and $0.5 \pm 0.5 \mathrm{ml} /$ day in the 13 control patients. Student's $t$ test on the difference between the means was not significant.

\begin{tabular}{lllll}
\hline Group & $\begin{array}{l}\text { No. of } \\
\text { Patients }\end{array}$ & $\begin{array}{l}\text { Mean } \\
\text { Basal Loss } \\
\text { (mllday) }\end{array}$ & $\begin{array}{l}\text { Mean } \\
\text { Aspirin Loss } \\
\text { (mllday) }\end{array}$ & $\begin{array}{l}\text { Mean } \\
\text { Increased Loss } \\
\text { due to Aspirin } \\
\text { (ml/day) }\end{array}$ \\
\hline Postgastrectomy patients & 18 & $0 \cdot 6 \pm(0 \cdot 5)$ & $2 \cdot 4 \pm(2 \cdot 1)$ & $1 \cdot 8 \pm(1 \cdot 7)$ \\
Controls & 19 & $0 \cdot 7 \pm(0 \cdot 7)$ & $4 \cdot 1 \pm(7 \cdot 8)$ & $3 \cdot 0 \pm(7 \cdot 5)$ \\
& 13 & $0 \cdot 5 \pm(0 \cdot 5)$ & $2 \cdot 6 \pm(2 \cdot 7)$ & $2 \cdot 2 \pm(2 \cdot 2)$ \\
& 14 & $0 \cdot 5 \pm(0 \cdot 5)$ & $4 \cdot 0 \pm(6 \cdot 1)$ & $3 \cdot 4 \pm(5 \cdot 9)$ \\
\hline
\end{tabular}

Table III Comparison between the mean faecal blood loss in postgastrectomy and control patients before, during, and after aspirin administration

'SD

\begin{tabular}{|c|c|c|c|c|c|c|}
\hline $\begin{array}{l}\text { Case } \\
\text { No. }\end{array}$ & Age & $\operatorname{Sex}$ & $\begin{array}{l}\text { Type of } \\
\text { Ulcer }\end{array}$ & $\begin{array}{l}\text { Date of } \\
\text { Operation }\end{array}$ & $\begin{array}{l}\text { Increased } \\
\text { Blood Loss } \\
\text { due to } \\
\text { Aspirin } \\
\text { (mllday) }\end{array}$ & Histological Report ${ }^{1}$ \\
\hline $\begin{array}{l}4 \\
9\end{array}$ & $\begin{array}{l}62 \\
46\end{array}$ & $\begin{array}{l}\mathbf{M} \\
\mathbf{F}\end{array}$ & $\begin{array}{l}\text { Gastric } \\
\text { Duodenal }\end{array}$ & $\begin{array}{l}1952 \\
1963\end{array}$ & $\begin{array}{l}0.9 \\
0.3\end{array}$ & $\begin{array}{l}\text { Atrophic gastritis grade II } \\
\text { Atrophic gastritis grade II } \\
\text { with moderate pyloric } \\
\text { metaplasia }\end{array}$ \\
\hline 10 & 61 & $\mathbf{M}$ & Gastric & 1952 & $1 \cdot 4$ & $\begin{array}{l}\text { Atrophic gastritis grade III } \\
\text { with pyloric and intestinal } \\
\text { metaplasia }\end{array}$ \\
\hline 12 & 66 & $\mathbf{M}$ & Duodenal & 1954 & n & $\begin{array}{l}\text { Atrophic gastritis grade II } \\
\text { with moderate pyloric } \\
\text { metaplasia }\end{array}$ \\
\hline 13 & 66 & $\mathbf{M}$ & $\begin{array}{l}\text { Gastric and } \\
\text { duodenal }\end{array}$ & 1962 & $2 \cdot 3$ & $\begin{array}{l}\text { Minor changes with some } \\
\text { focal groups of round cells, } \\
\text { miscellaneous group }\end{array}$ \\
\hline 16 & 61 & $\mathbf{M}$ & $\begin{array}{l}\text { Gastric and } \\
\text { duodenal }\end{array}$ & 1948 & 0.9 & Atrophic gastritis grade II \\
\hline 18 & 46 & $\mathbf{F}$ & Duodenal & 1961 & 0.5 & $\begin{array}{l}\text { Round cell infiltration; } \\
\text { miscellaneous group }\end{array}$ \\
\hline 19 & 62 & $\mathbf{F}$ & Duodenal & 1952 & $2 \cdot 0$ & $\begin{array}{l}\text { Atrophic gastritis grade II } \\
\text { with moderate pyloric } \\
\text { metaplasia }\end{array}$ \\
\hline 20 & 58 & $\mathbf{F}$ & Duodenal & 1952 & $0 \cdot 7$ & Atrophic gastritis grade I \\
\hline
\end{tabular}

Table IV Histological appearance of gastric biopsies in nine post-gastrectomy anaemic patients

${ }^{1}$ Grading of Atrophic Gastritis ( $D r$ A. Knudsen):

Grade I: up to $50 \%$ atrophy of body glands

Grade II: $50-90 \%$ atrophy of body glands

Grade III: $90-100 \%$ atrophy of body glands with a variable degree of pyloric or intestinal metaplasia

Blood loss due to aspirin in 18 postgastrectomy patients was $2 \cdot 4 \pm 2.1 \mathrm{ml} /$ day and $2 \cdot 6 \pm 2.7 \mathrm{ml} /$ day in the controls which again did not attain statistical significance. The pattern of blood loss after aspirin was a gradual increase up to a peak, and when the aspirin was stopped there was a gradual tapering off to basal levels. This was identical in both anaemic and control subjects (Fig. 2).

Increased bleeding due to aspirin appeared less in the postgastrectomy group $(1.8 \pm 1.7 \mathrm{ml} /$ day $)$ compared with the controls $(2 \cdot 1 \pm 2 \cdot 2 \mathrm{ml} /$ day $)$ but these differences were very small and did not

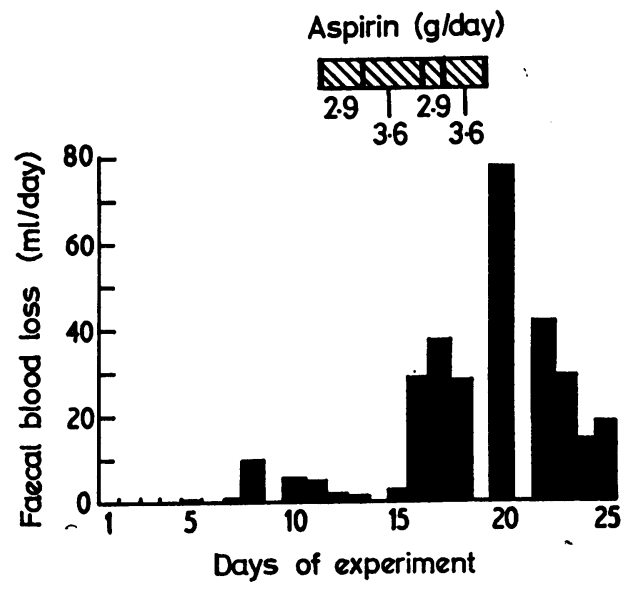

Fig. 1 Excessive aspirin bleeding in a postgastrectomy male patient.

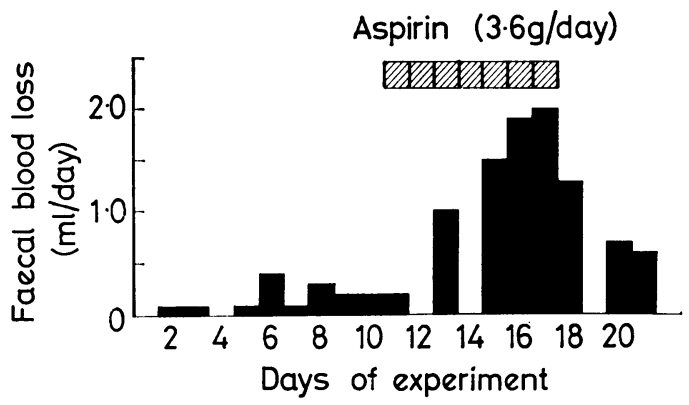

Fig. 2 The normal pattern of blood loss after aspirin administration.

teach significance on the $t$ test. When the means were recalculated with the addition of the two bleeders, one in each group, the findings were not altered.

COMPARISONS BETWEEN THE SEVERITY OF THE ATROPHIC GASTRITIS AND GASTROINTESTINAL BLEEDING

Seventeen biopsies were obtained in nine patients and all showed changes of gastritis (Table IV). The changes were independently graded by one observer who was unaware of the blood loss results. The changes included minor abnormalities, such as increased cellular infiltration and oedema of the mucosa (miscellaneous group), to atrophic gastritis of varying degree (Figs. 2 and 3). There was no correlation between the degree of atrophic gastritis and the amount of occult blood loss (Table IV). 

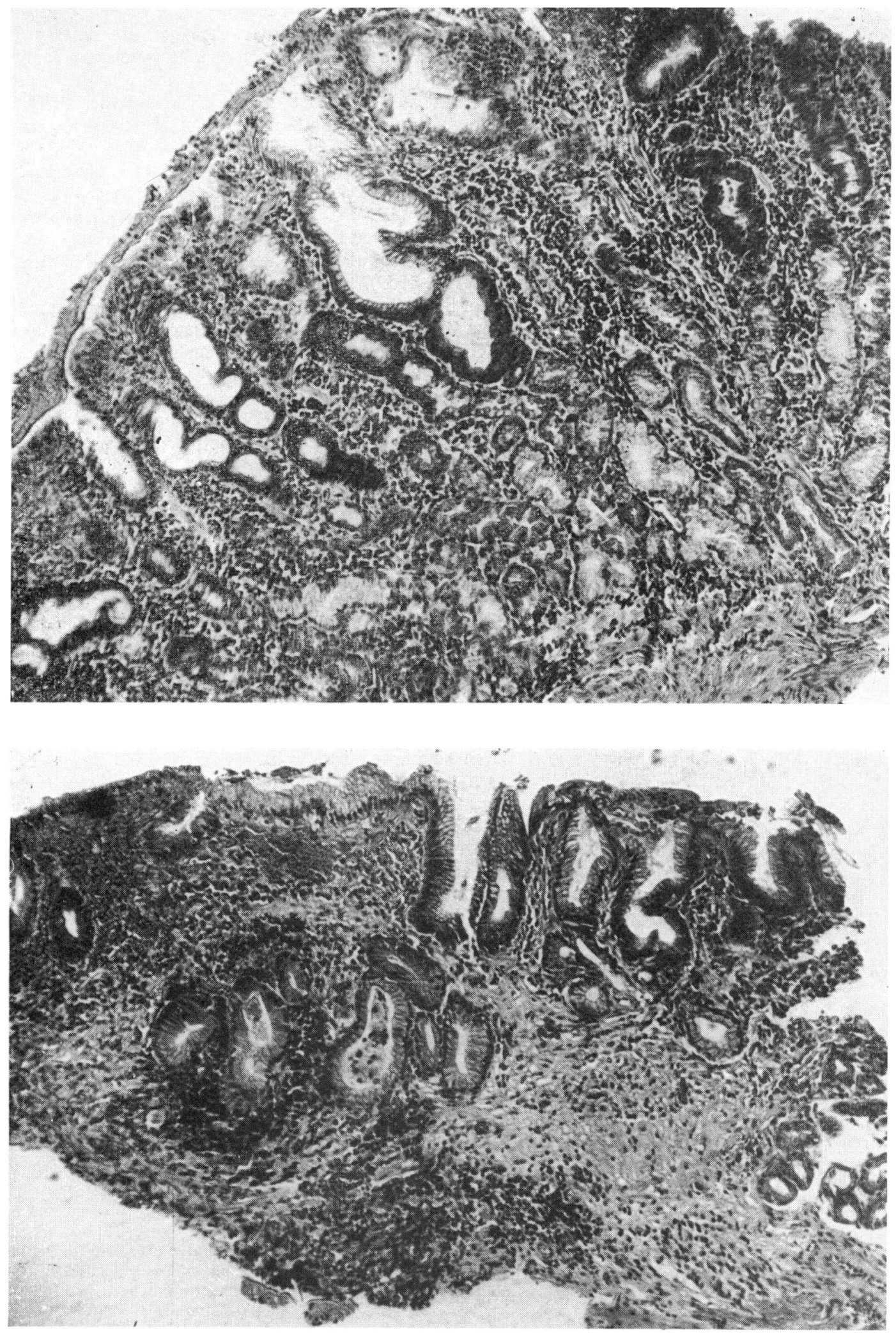

Fig. 3 Grade I atrophic gastritis showing partial atrophy of body glands which have been replaced by metaplastic glands of pyloric type (above). There is moderate diffuse round cell infiltration.

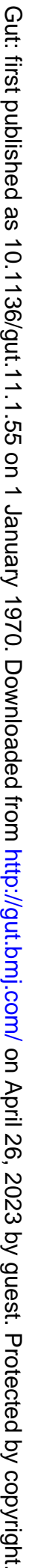

Fig. 4 Grade III gastric atrophy showing absence of gastric body glands (below). A group of metaplastic pyloric glands and sparse round cell infiltration. 


\section{Discussion}

The incidence of iron-deficiency anaemia after partial gastrectomy is $28 \%$ in 33 reports comprising 7,505 postgastrectomy subjects (Deller and Witts, 1962) and most observers have suspected that continuous or intermittent leaking of blood from the stoma, gastric remnant, or jejunum may play a part in the pathogenesis of this anaemia.

Investigators using chemical occult blood tests have found negative results (Lyngar, 1950; Blake and Rechnitzer, 1953; Baird et al, 1959). However, these chemical tests are of limited value and may occasionally fail to detect volumes of blood up to $10 \mathrm{ml}$ daily (Ross and Gray, 1964). A more accurate estimation of blood loss is obtained in the present study of the radiochromium-labelled red cell method which can detect quantities of less than $0.5 \mathrm{ml}$ of blood.

Kimber et al (1967) also measured gastrointestinal blood loss after partial gastrectomy using the same method and reported losses of between 3.2 and $6.5 \mathrm{ml} /$ day of blood in six out of eight anaemic postgastrectomy patients before treatment of the iron-deficiency anaemia. One patient in this group had menorrhagia; all but one of these patients had lost blood.

However, in the present study there was no significant difference between gastrointestinal blood loss in 18 anaemic postgastrectomy and 13 control subjects. These findings agree with those of .Stevens et al (1959) who only found bleeding in two out of seven similar patients, and this bleeding was shown to be from sites unrelated to the previous gastric surgery. Our present investigations were made after correction of the anaemia, compared with those of Kimber et al, but it is unlikely that treatment altered any gastrointestinal occult blood loss.

One important clinical implication of the present findings is that consistently positive occult blood tests in a patient who is anaemic after partial gastrectomy indicate the need for a careful search for sites of bleeding. Other sites of bleeding besides the stoma and the gastric remnant should be excluded.

There was no correlation between intake of aspirin and severity of anaemia in our postgastrectomy patients. The one patient who admitted taking aspirin every day had a blood loss of $1.9 \mathrm{ml} /$ day when taking $3.6 \mathrm{~g} /$ day of soluble aspirin. As his usual intake varied from 0.6 to $1.8 \mathrm{~g}$ /day of soluble aspirin, his mean daily blood loss would probably be normally under $1.0 \mathrm{ml}$. These findings confirm Hobbs's (1961) observation that anaemic postgastrectomy patients do not consume more aspirin than non-anaemic postgastrectomy patients.

The aim of the present study was to submit the postgastrectomy anaemic patient to the maximum stimulus for bleeding by administering a large dose of aspirin. In this way any hidden bleeding tendency may become evident. The results show that there is no difference between normal controls and postgastrectomy anaemic subjects. The latter group appear to bleed slightly less after aspirin, but this diminished bleeding does not reach statistical significance. The present findings agree with those of Croft and Wood (1967) who also found no difference in the pattern of susceptibility to aspirin after partial gastrectomy compared with non-gastrectomy controls. However, these authors did not mention the haematological status of their patients, and the purpose of the present study was to investigate those postgastrectomy patients who had already become anaemic. If aspirin bleeding were a factor in anaemia after partial gastrectomy these patients should demonstrate occult blood loss when given a large dose of aspirin. However, no abnormal susceptibility to aspirin was found.

Atrophic gastritis was present in varying degree in all the gastric biopsies. In many instances pyloric metaplasia was present. There was no correlation between the degree of the gastrointestinal bleeding and the severity of the gastritis. The diminished bleeding due to aspirin in the anaemic postgastrectomy patient with atrophic gastritis compared with the controls did not attain statistical significance. The therapeutic administration of aspirin is therefore not contraindicated in patients after gastrectomy but large and regular amounts of aspirin should be avoided because of the precarious iron balance in the postgastrectomy state. Intermittent bleeding is a possible cause for postgastrectomy anaemia and the present observations of occult blood loss have only been for periods of three weeks. It is conceivable that longer periods of study may still show intermittent occult bleeding. All 20 patients who had become anaemic after partial gastrectomy failed to show any such episodes of intermittent bleeding and this possibility is remote.

It is likely that the malabsorption of dietary iron which is known to be present after gastrectomy places the iron balance in these patients in a critical state. In many patients it is the only cause of the anaemia, and they are unable to make up physiological losses of iron. In other patients if there is any blood loss, eg, from excessive menstrual loss, or from haemorrhoids, the onset of anaemia is usually abrupt, because of the failure to augment iron absorption to compensate for the increased loss of iron.

We gratefully acknowledge the help and cooperation of the physicians and surgeons of the West Middlesex Hospital in allowing us to investigate their patients, in particular Dr J. S. Stewart who also gave us much valuable advice and enthusiasm. Mr D. Kemp referred many of the patients he was studying to us.

We are greatly indebted to $\mathrm{Mr} D$. Rees and $\mathrm{Dr}$ S. S. Stewart, of the Department of Medical Physics, Mount Vernon Hospital, for their advice. Dr P, 
MacDonald, Department of Statistics, Brunel University, advised on statistical methods.

We are very grateful to Dr A. Knudsen for the gastric biopsy reports. We thank the Photographic Department, West Middlesex Hospital, for the figures.

\section{References}

Baird, I. McL., Blackburn, E. K., and Wilson, G. M. (1959). The pathogenesis of anaemia after partial gastrectomy: 1. Development of anaemia in relation to time after operation, blood loss, and diet. Quart. J. Med., 28, 21-34.

Baird, I. McL., and Wilson, G. M. (1959). The pathogenesis of anaemia after partial gastrectomy. 2. Iron absorption after partial gastrectomy. Quart. J. Med., 28, 35-41.

Blake, J., and Rechnitzer, P. A. (1953). The haematological and nutritional effects of gastric operations. Quart. J. Med., 22, 419-437.

Coghill, N. F., and Williams, A. W. (1955). Gastric biopsy with a modified Australian instrument. Brit. med. J., 11, 1111-114.

Croft, D. N., and Wood, P. H. N. (1967). Gastric mucosa and susceptibility to occult gastrointestinal bleeding caused by aspirin. Brit. med. J., 1, 137-141.

Deller, D. J., and Witts, L. J. (1962). Changes in the blood after partial gastrectomy with special reference to vitamin $\mathbf{B}_{\mathbf{1 2}}$. Quart. J. Med., 31, 61-88.

Hobbs, J. (1961). Iron deficiency after partial gastrectomy. Gut, 2, 141-149.

Kimber, C., Patterson, J. F., and Weintraub, L. R. (1967). The pathogenesis of iron deficiency anaemia following partial gastrectomy. J. Amer. med Ass., 202, 935-938.

Lyngar, E. (1950). Blood changes after partial gastrectomy for ulcer. Acta. med. scand., suppl. 247, p. 11.
Mollison, P. L. (1961). Further observations on the normal survival curve of ${ }^{31} \mathrm{Cr}$-labelled red cells. Clin. Sci., 21 , 21-36.

Owen, C. A., Jr., Bollman, J. L., and Grindlay, J. H. (1954). Radiochromium-labelled erythrocytes for the detection of gastrointestinal haemorrhage. J. Lab. clin. Med., 44, 238-345.

Ross, G., and Gray, C. H. (1964). Assessment of routine tests for occult blood in faeces. Brit. med. J., 1, 1351-1354.

Stevens, A. R., Pirzio-Biroli, G., Harkins, H. N., Nyhus, L. M., and Finch, C. A. (1959). Iron metabolism in patients after partial gastrectomy. Ann. Surg., 149, 534-538.

Turnberg, L. A. (1966). The absorption of iron after partial gastrectomy. Quart. J. Med., 35, 107-118.

Wood, I. J., Doig, R. K., Motteram, R., and Hughes, A. (1949). Gastric biopsy: report on fifty-five biopsies using a new flexible gastric biopsy tube. Lancet, 1, 18-21. 